LIDAR-DERIVED ELEVATION MODELS FOR THE GREWINGK GLACIER 1967 LANDSLIDE SCAR, ALASKA, COLLECTED JUNE 3, 2019

J. Barrett Salisbury, Andrew M. Herbst, and Ronald P. Daanen

Raw Data File 2021-6

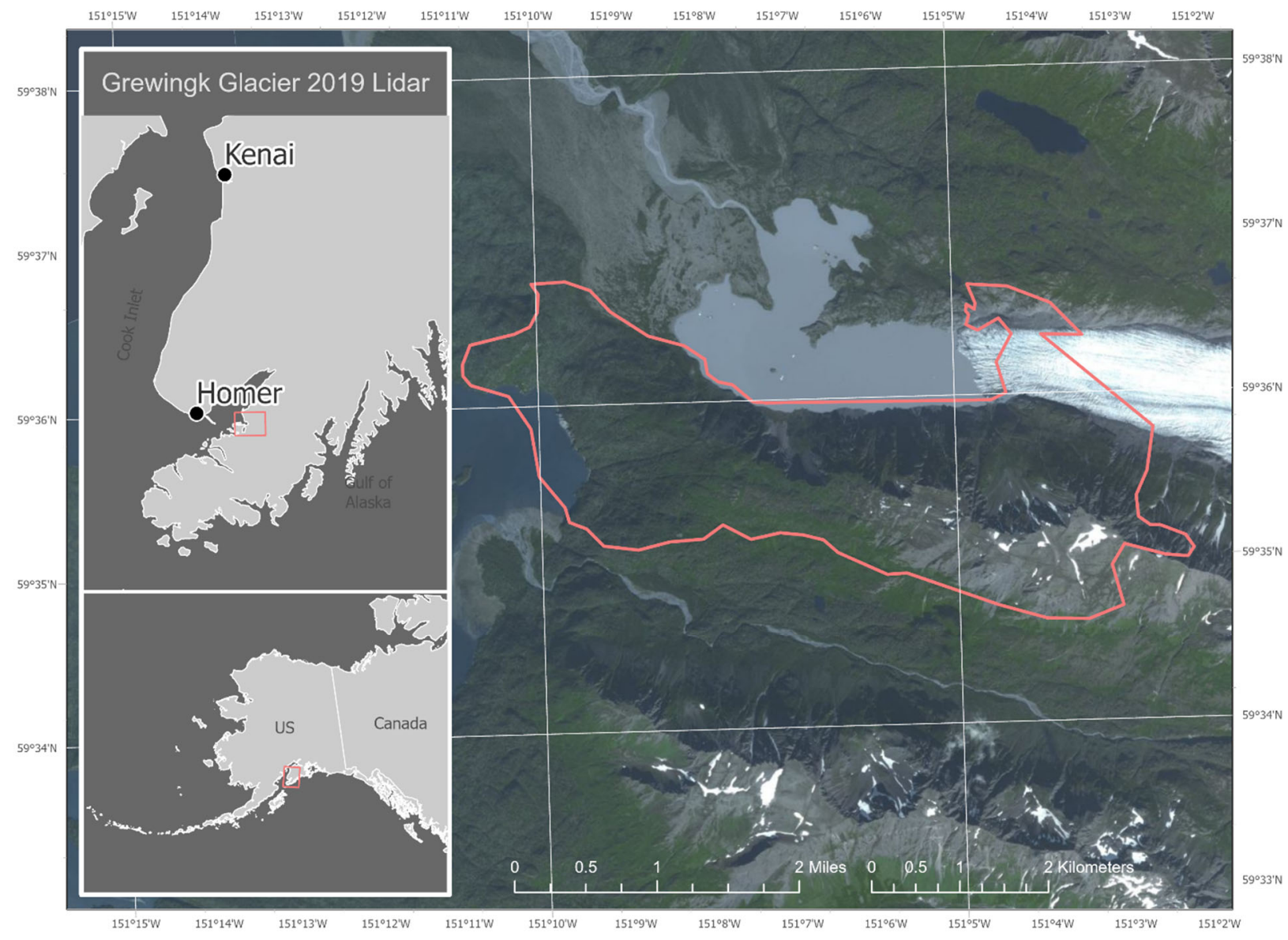

This report has not been reviewed for technical content or for conformity to the editorial standards of DGGS.

2021

STATE OF ALASKA

DEPARTMENT OF NATURAL RESOURCES

DIVISION OF GEOLOGICAL \& GEOPHYSICAL SURVEYS
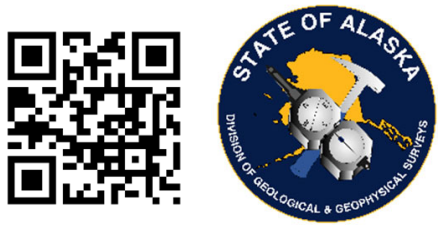
STATE OF ALASKA

Mike Dunleavy, Governor

DEPARTMENT OF NATURAL RESOURCES

Corri A. Feige, Commissioner

\section{DIVISION OF GEOLOGICAL \& GEOPHYSICAL SURVEYS}

Steve Masterman, State Geologist \& Director

Publications produced by the Division of Geological \& Geophysical Surveys are available to download from the DGGS website (dggs.alaska.gov). Publications on hard-copy or digital media can be examined or purchased in the Fairbanks office:

\section{Alaska Division of Geological \& Geophysical Surveys (DGGS)}

3354 College Road | Fairbanks, Alaska 99709-3707

Phone: 907.451 .5010 | Fax 907.451.5050

dggspubs@alaska.gov | dggs.alaska.gov

DGGS publications are also available at:

Alaska State Library, Historical

Collections \& Talking Book Center

395 Whittier Street

Juneau, Alaska 99801

Alaska Resource Library and

Information Services (ARLIS)

3150 C Street, Suite 100

Anchorage, Alaska 99503

\section{Suggested citation:}

Salisbury, J.B., Herbst, Andrew M., and Daanen, Ronald P., 2020, Lidarderived elevation models for the Grewingk Glacier 1967 landslide scar, Alaska, collected June 3, 2019: Alaska Division of Geological \& Geophysical Surveys Raw Data File 2020-6, 7 p.

https://doi.org/10.14509/30599
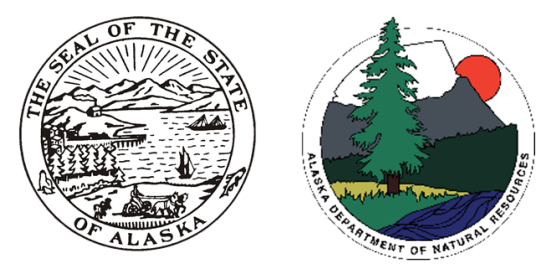


\title{
LIDAR-DERIVED ELEVATION MODELS FOR THE GREWINGK GLACIER 1967 LANDSLIDE SCAR, KACHEMAK BAY, ALASKA, COLLECTED JUNE 3, 2019
}

\author{
J. Barrett Salisbury ${ }^{1}$, Andrew M. Herbst ${ }^{1}$, and Ronald P. Daanen ${ }^{1}$
}

\section{INTRODUCTION}

The Alaska Division of Geological \& Geophysical Surveys (DGGS) used lidar to produce digital terrain models (DTM), a digital surface model (DSM), and an intensity model for evaluations of the Grewingk Glacier 1967 landslide scar located above the proglacial lake on the north-facing flank of the glacial valley in Kachemak Bay State Park, Alaska. DGGS capitalized on a data collect (Salisbury and others, 2021) conducted in Homer the same day for a landslide hazard resiliency project. Lidar and Global Navigation Satellite System (GNSS) data were collected on June 3, 2019, and subsequently processed using TerraSolid ${ }^{\mathrm{Tm}}$ and ArcGIS ${ }^{\mathrm{TM}}$. The Alaska Division of Mining, Land, \& Water (DMLW) Survey Section conducted a targeted Ground Control Survey for the Homer project on June 19-20, 2019, and we use these ground control data for the Grewingk Glacier dataset across Kachemak Bay. These data are being released as a Raw Data File with an open end-user license. All files can be downloaded for free from the DGGS publications website at https://doi.org/10.14509/30599.

\section{LIST OF DELIVERABLES}

- Classified Points

- Digital Surface Model (DSM)

- Digital Terrain Model (DTM)

- Hydro-Flattened DTM

- Lidar Intensity Image

- Metadata

\section{MISSION PLAN}

\section{Aircraft and Instrument}

DGGS operates a Riegl VUX1-LR laser scanner with a GNSS and Northrop Grumman Inertial Measurement Unit (IMU). The integration was designed by Phoenix LiDAR systems. The sensor can collect up to 820,000 points per second over a $150 \mathrm{~m}$ range. We flew the instrument with a repetition rate of 400,000 to 820,000 pulses per second, a scan speed of 200 revolutions per second, at approximately $150 \mathrm{~m}$ above ground level, and at a ground speed of approximately 40 meters per second with a fixed-wing Cessna 185. The scan look angle operated between 55 and 305 degrees. The total data coverage is approximately $16.31 \mathrm{~km}^{2}$.

${ }^{1}$ Alaska Division of Geological \& Geophysical Surveys, 3354 College Road, Fairbanks, Alaska 99709 


\section{Weather Conditions and Flight Times}

DGGS collected lidar data in the Homer area on June 3, 2019, initiating the GNSS base station at 8:48 am and flying from 10:15 am to $3: 35 \mathrm{pm}$ with a 15-minute refuel at 2:15 pm. Data for the Grewingk Glacier landslide scar were collected in the afternoon from 2:30 pm to 3:35 pm after the plane refuel stop (fig. 1). The sky was clear with light, easterly winds. Patchy snow cover was present along the ridgeline during the survey.

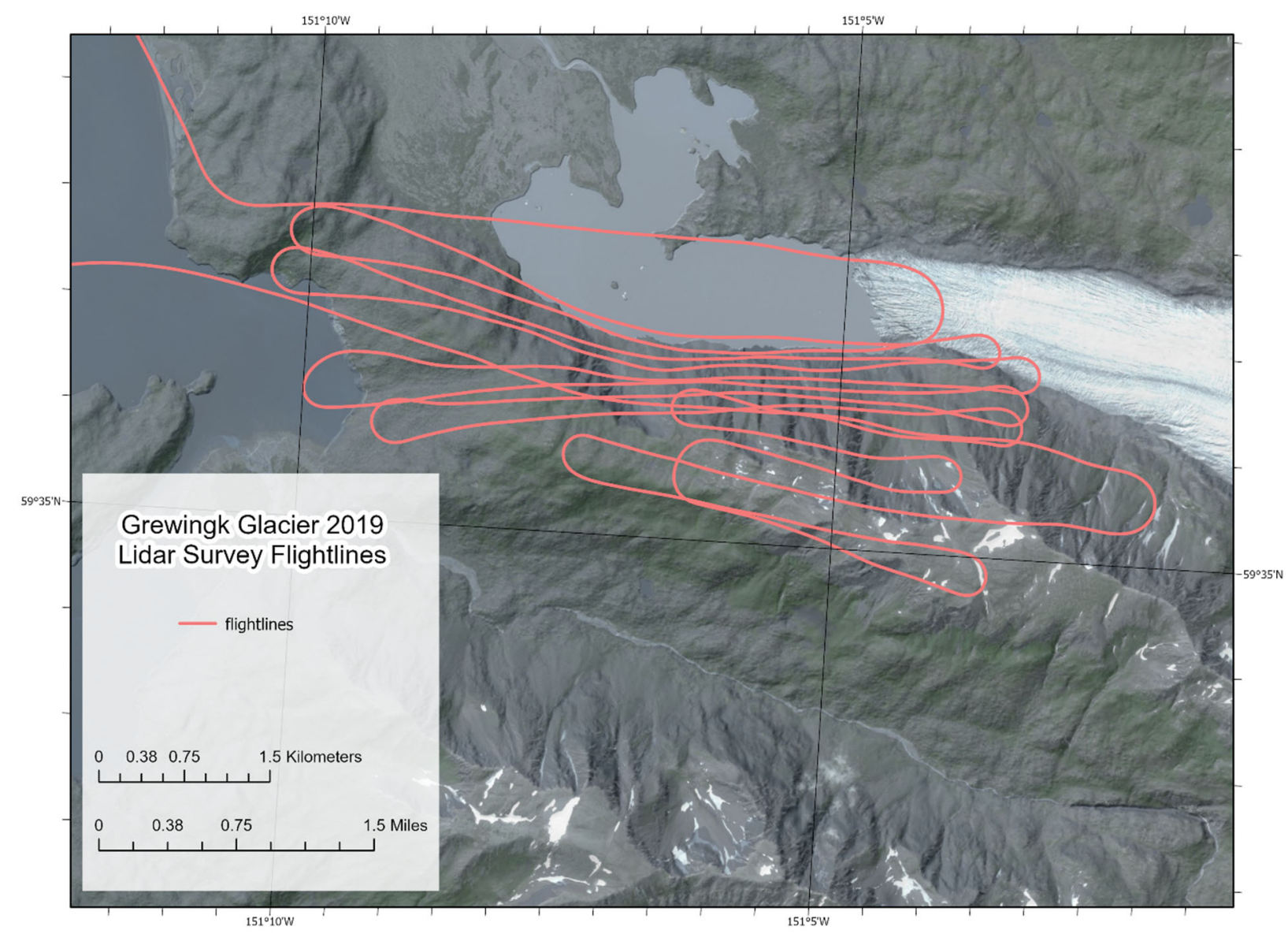

Figure 1. Project flight-lines.

\section{PROCESSING REPORT}

\section{Lidar Dataset Processing}

DGGS processed raw data by first using SDCImport ${ }^{\mathrm{Ti}}$ to apply range thresholding, reflectance thresholding, and missed-time-around (MTA) disambiguation for preliminary point cloud noise filtering. We coupled in-flight IMU and GNSS data in Inertial Explorer ${ }^{\mathrm{rm}}$ to produce flight trajectory data and coupled the trajectory data with the raw point cloud in Spatial Explorer ${ }^{\mathrm{rm}}$. 
We then used Terrasolid ${ }^{\text {Tn }}$ to calibrate point cloud data using tielines for roll, pitch, and yaw of the aircraft during the survey. We completed this process first for all points, then on a perflight-line basis. For additional calibration, we identified interswath fluctuations in preliminarily classified ground points using overlapping tielines. We classified the point cloud in accordance with American Society for Photogrammetry and Remote Sensing (ASPRS) guidelines using project-tailored macros, resulting in a ground points class, as well as low, medium, and high vegetation (0.01-0.3 $\mathrm{m}, 0.3-5 \mathrm{~m}$, and 5-60 $\mathrm{m}$ heights above the ground, respectively).

Misclassified points were manually reclassified in post-processing QA/QC. We eliminated all low points and air points from the dataset. We converted the point cloud from ellipsoidal to orthometric heights using GEOID 12B, then uniformly vertically adjusted the dataset (based on ground control collected in Homer) to minimize vertical offset.

All derivative products were created in ArcMap ${ }^{\mathrm{Tx}}$. The DTM and DSM were produced using point triangulation with nearest-neighbor interpolation. The DTM was derived from all returns for ground classified points, while the DSM used first returns for all non-noise classes. A lidar intensity image was created from first returns of all classes using mean binning.

\section{Classified Point Cloud}

Classified point cloud data is provided in this collection in compressed ${ }^{*}$. LAZ format. Data are classified in accordance with ASPRS 2014 guidelines and contain return and intensity information. The average point spacing is $54.07 \mathrm{~cm}$ and the average point density is 3.42 points per square meter (fig. 2). Elevation surfaces interpolated from areas with a point density of fewer than $2 \mathrm{pts} / \mathrm{m}^{2}$ were designated as "low confidence areas" (fig. 3), rather than classified as nodata. This decision was made to preserve the visual consistency of the data while remaining forthright about its quality.

\section{Digital Surface Model}

The DSM represents surface elevations as they appear to the naked eye, including the heights of vegetation, buildings, bridges, etc. The DSM is a single band, 32-bit GeoTIFF file, with a ground sample distance of 0.5 meters. No Data value is set to $-3.40282306074 \mathrm{e}+038$.

\section{Digital Terrain Model}

The DTM represents surface elevations of ground surfaces, achieved by penetrating or flattening any vegetation, bridges, buildings, and other non-ground features. The DTM is a singleband, 32-bit float GeoTIFF file, with a ground sample distance of 0.5 meters. No Data value is set to $-3.40282306074 \mathrm{e}+038$ (the 32-bit, floating-point minimum).

\section{Hydro-Flattened DTM}

The hydro-flattened DTM represents bare earth surfaces that have undergone a selective "flattening" process, where elevation values for any hydrologic features are replaced with a consistent, appropriate pixel (elevation) value. The hydro-enforced DTM is a single-band, 32-bit 
float GeoTIFF file, with a ground sample distance of 0.5 meters. No Data value is set to $3.40282306074 \mathrm{e}+038$.

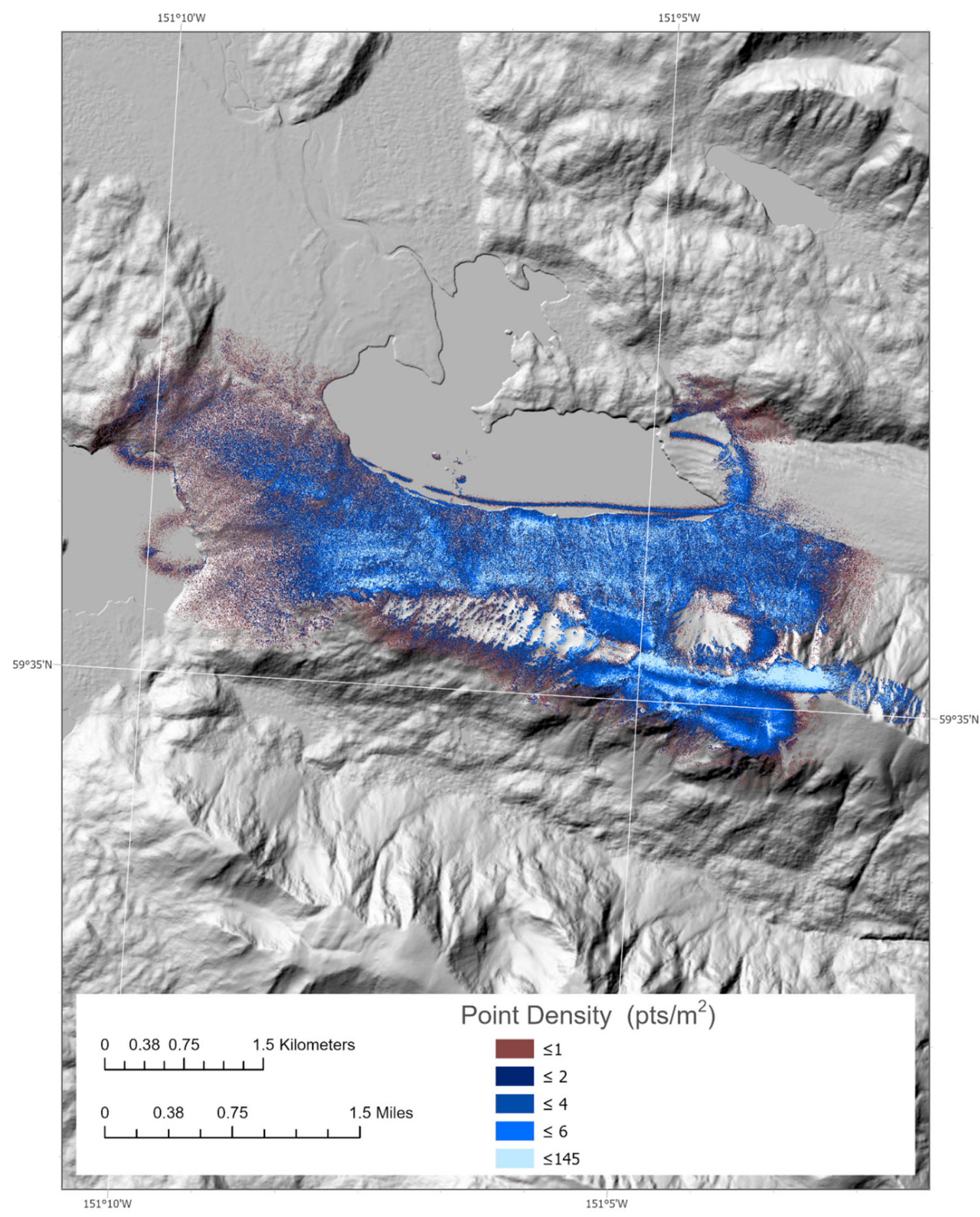

Figure 2. Point density displayed as 1-meter raster for the survey. Note that individual map pixels are not necessarily visible at this map scale. 


\section{Lidar Intensity Image}

The lidar intensity image describes the relative amplitude of reflected signals contributing to the point cloud. Lidar intensity is largely a function of scanned object reflectance in relation to the signal frequency, is dependent on ambient conditions, and is not necessarily consistent between separate scans. The intensity image is a single-band, 32-bit float GeoTIFF file with a ground sample distance of 0.5 meters. No Data value is set to $-3.40282306074 \mathrm{e}+038$.
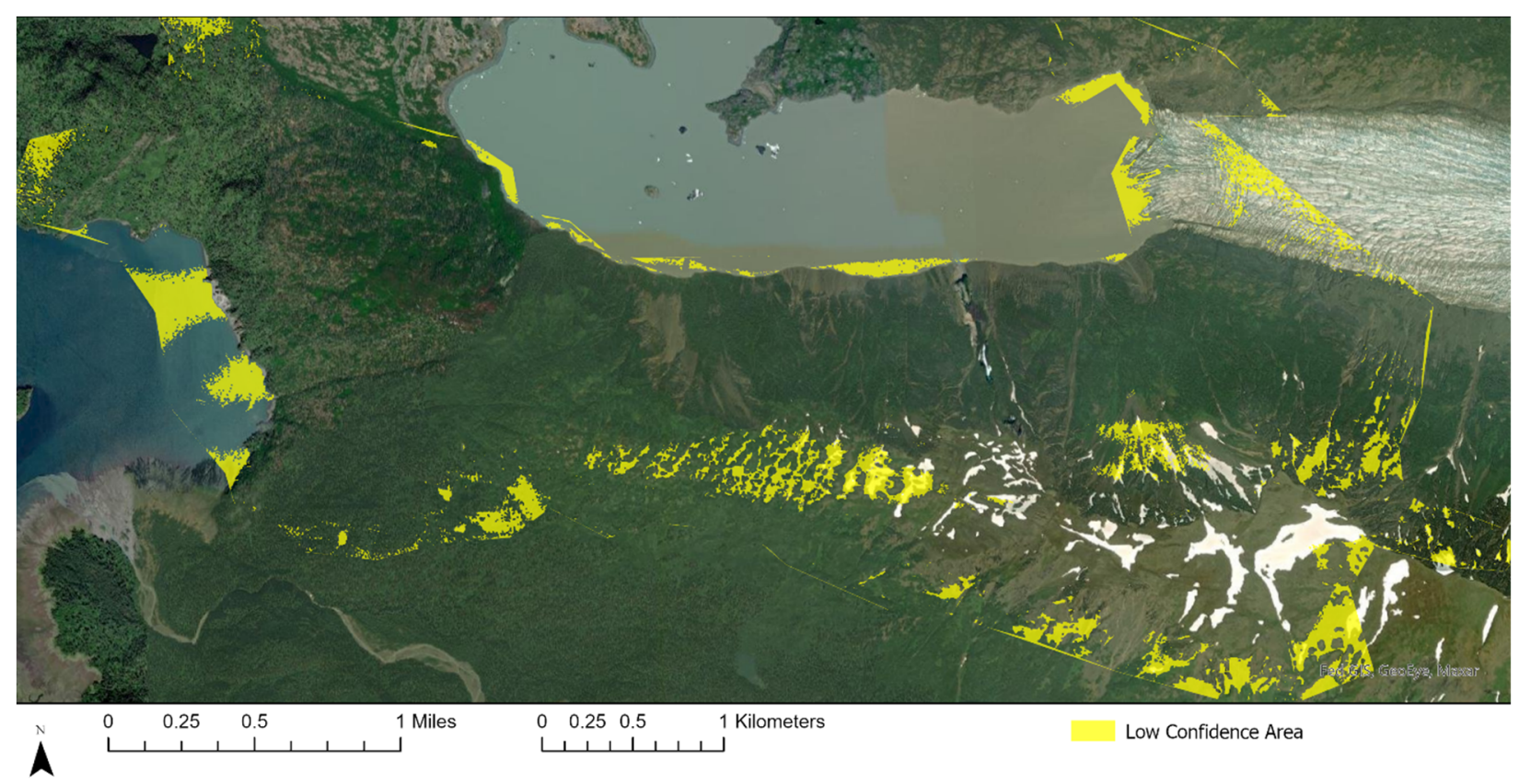

Figure 3. Low confidence areas measured as having fewer than 2 points per square meter.

\section{SURVEY REPORT}

\section{Ground Control and Accuracy}

The Alaska Division of Mining, Land, \& Water Survey Section collected 79 points in a targeted Ground Control Survey in Homer on June 19-20, 2019. We use these ground control data for the Grewingk dataset, as the lidar collection was continuous from one study area to the next.

\section{Coordinate System and Datum}

All data are processed and delivered in NAD83 (2011) UTM 5N and vertical datum NAVD88 GEOID12B.

\section{Horizontal Accuracy}

Horizontal accuracy was not measured for this collection.

\section{Vertical Accuracy}

No ground control was collected for this dataset. However, these data share relative accuracy properties with another dataset in Homer, for which an RMSE of $3.1 \mathrm{~cm}$ was evaluated. 
The relative accuracy between these two datasets was measured at $1.18 \mathrm{~cm}$ RMSE, calculated as the inter-swath consistency.

\section{Data Consistency and Completeness}

This is a partial release dataset. Data for the Grewingk Glacier 1967 landslide scar were collected at the end of the day (June 3, 2019), after collection of Homer data was complete and the plane was refueled. Data quality portrayed here is based on the Homer dataset, as we have no ground control across Kachemak Bay. However, we ran the lidar scanner continuously all day and quality should be consistent throughout the Homer and Grewingk datasets.

\section{ACKNOWLEDGMENTS}

These data products were funded by the State of Alaska and collected and processed by Alaska Division of Geological \& Geophysical Surveys staff. The Homer lidar dataset and ground control referenced above was funded by the Federal Emergency Management Agency (FEMA) through Cooperating Technical Partnership (CTP) with the City of Homer and AK DGGS under federal grant number CTP EMS-2018-CA-00016-S01. We thank Clearwater Air for their aviation expertise and contribution to these data products.

\section{REFERENCES}

Salisbury, J.B., Daanen, R.P., and Herbst, A.M., 2021, Lidar-derived elevation models for Homer, Alaska: Alaska Division of Geological \& Geophysical Surveys Raw Data File 2021-2, 6 p. https://doi.org/10.14509/30591 
Appendix 1. Checkpoints in Homer

\begin{tabular}{|c|c|c|c|c|c|}
\hline Number & Easting (m) & Northing (m) & $\begin{array}{l}\text { Known Z } \\
\text { (m) }\end{array}$ & $\begin{array}{l}\text { Laser Z } \\
\text { (m) }\end{array}$ & $\begin{array}{l}\text { Dz Elevation } \\
\text { Difference (m) }\end{array}$ \\
\hline BE_5004 & 580635.927 & 6612533.982 & 53.735 & 53.75 & 0.015 \\
\hline BE_5011 & 577684.323 & 6613704.249 & 221.075 & 221.07 & -0.005 \\
\hline BE_5013 & 582089.658 & 6612343.381 & 22.083 & 22.08 & -0.003 \\
\hline BE_5058 & 581728.378 & 6616717.417 & 285.834 & 285.85 & 0.016 \\
\hline BE_5066 & 583843.713 & 6615651.758 & 357.632 & 357.67 & 0.038 \\
\hline BE_5073 & 586770.381 & 6617829.908 & 425.181 & 425.2 & 0.019 \\
\hline BENCHMARK_BM 4 & 589714.493 & 6608107.084 & 7.712 & 7.71 & -0.002 \\
\hline NAIL_NAIL 3 & 588041.324 & 6615621.985 & 28.434 & 28.54 & 0.106 \\
\hline URBAN_5008 & 579796.212 & 6612613.893 & 67.457 & 67.41 & -0.047 \\
\hline URBAN_5010 & 577672.012 & 6613710.098 & 221.541 & 221.52 & -0.021 \\
\hline URBAN_5034 & 588021.495 & 6615616.825 & 28.081 & 28.09 & 0.009 \\
\hline URBAN_5051 & 580326.407 & 6614882.079 & 284.171 & 284.15 & -0.021 \\
\hline URBAN_5068 & 585452.944 & 6616387.049 & 344.232 & 344.22 & -0.012 \\
\hline URBAN_5072 & 586768.984 & 6617806.595 & 424.992 & 425.01 & 0.018 \\
\hline BE_5006 & 579733.917 & 6612602.377 & 64.482 & 64.47 & -0.012 \\
\hline BE_5037 & 589369.308 & 6616889.273 & 75.511 & 75.48 & -0.031 \\
\hline BE_5044 & 584781.612 & 6614377.014 & 56.403 & 56.39 & -0.013 \\
\hline BE_5052 & 580330.363 & 6614870.042 & 283.271 & 283.25 & -0.021 \\
\hline BE_5069 & 585443.523 & 6616397.515 & 343.668 & 343.7 & 0.032 \\
\hline PK_PK 1 & 583850.691 & 6615639.49 & 357.836 & 357.86 & 0.024 \\
\hline PK_PK 2 & 580636.745 & 6612538.878 & 53.408 & 53.42 & 0.012 \\
\hline URBAN_5023 & 587575.238 & 6609392.438 & 7.495 & 7.46 & -0.035 \\
\hline URBAN_5043 & 584801.463 & 6614351.444 & 54.461 & 54.46 & -0.001 \\
\hline URBAN_5061 & 581850.268 & 6615457.607 & 328.778 & 328.78 & 0.002 \\
\hline Average dz (m) & 0.003 & & & & \\
\hline Minimum dz (m) & -0.047 & & & & \\
\hline Maximum dz (m) & 0.106 & & & & \\
\hline $\begin{array}{l}\text { Average } \\
\text { magnitude }(\mathrm{m})\end{array}$ & 0.021 & & & & \\
\hline $\begin{array}{l}\text { Root mean square } \\
\text { error }(m)\end{array}$ & 0.03 & & & & \\
\hline $\begin{array}{l}\text { Standard } \\
\text { Deviation (m) }\end{array}$ & 0.031 & & & & \\
\hline
\end{tabular}

